\title{
Glucosylglycerol accumulation during salt acclimation of two unicellular cyanobacteria
}

\author{
Norbert Erdmann, ${ }^{*}$ Sabine Fulda and Martin Hagemann \\ Department of Biology, University of Rostock, 2500 Rostock, FRG
}

(Received 26 June 1991; revised 14 October 1991; accepted 7 November 1991)

\begin{abstract}
A turbidostat culture technique was used to study the effects of different salt shocks on the freshwater cyanobacteria Synechocystis sp. strain PCC 6803 and Microcystis firma. Shocks were performed either suddenly or gradually, on both unacclimated cultures and those pre-acclimated to $0.77 \mathrm{M}-\mathrm{NaCl}$. All suddenly shocked cultures exhibited a decline in growth after a few hours, characterized by severely decreased metabolic activities (e.g. photosynthesis, respiration, glucose-6-phosphate dehydrogenase activity) and a time course of restoration which coincided with the accumulation of glucosylglycerol. Additionally, all untreated cultures had a late (after a few days) growth depression, distinguished by the stagnation of cell division. This was overcome by physiological adaptation of the whole cells or selection of cells with superior salt tolerance. The different types of growth depressions and the unique pattern of glucosylglycerol accumulation led to the conclusion that glucosylglycerol was necessary to maintain metabolic processes, but that this alone cannot account for successful salt acclimation.
\end{abstract}

\section{Introduction}

Salt acclimation is a complex process important to all organisms living in brackish-water habitats. To survive such unfavourable conditions, several different physiological strategies have evolved, such as salt-resistant enzymes, the exchange of $\mathrm{K}^{+}$for toxic $\mathrm{Na}^{+}$, and the accumulation of compatible solutes. The latter is commonly found in micro-organisms, algae and higher plants and includes at least four subprocesses.

Firstly, activation of a plasma-membrane-bound ion pump to export $\mathrm{Na}^{+}$. In cyanobacteria, a $\mathrm{Na}^{+} / \mathrm{H}^{+}$ antiport has been characterized (Molitor et al., 1990), which is accompanied by enhanced respiration, increased cytochrome oxidase activity (Jeanjean et al., 1990; Molitor et al., 1990) and glucose-6-phosphate dehydrogenase activity (G6PDH) which provides the respiratory substrate (Hagemann et al., 1989).

Secondly, the accumulation of compatible solutes (low molecular mass hydrophilic compounds) which substitute ions for their osmotic function and are more or less nontoxic, even at high concentrations (recent reviews: Reed \& Stewart, 1988; Trüper \& Galinski, 1989; Csonka 1989; Kirst 1990).

\footnotetext{
* Author for correspondence. Tel. (003781) 395328; fax (003781) 34287.

Abbreviations: $\mathrm{Chl} a$, chlorophyll $a$; G6PDH, glucose-6-phosphate dehydrogenase.
}

Thirdly, ultrastructural changes, especially a reduction of the permeability of the plasma membrane (Apte et al., 1987; Rivière et al., 1990). The change in permeability is brought about by enhanced lipid content (Gimmler \& Hartung, 1988) and/or alteration of lipid composition (Russell, 1989).

Fourthly, altered gene expression leading to modifications in the pattern of protein synthesis and the appearance of stress proteins (Apte \& Bhagwat, 1989; Hagemann et al., 1990). Sadka et al. (1989) have, however, questioned whether differential gene expression is really involved.

Although temporal and isotonic substitutions of ions as well as compatible solutes have been reported (Reed $e t$ al., 1985), little is known about other temporal or any causal relations of the adaptive subprocesses. The present study was conducted to assess the role of the accumulation of glucosylglycerol, a compatible solute found in moderately salt-tolerant cyanobacteria (Reed \& Stewart, 1988). In simultaneous acclimation experiments, cyanobacteria were subjected to different salt shocks and the time course of glucosylglycerol accumulation and associated physiological parameters were measured. For such parallel experiments, the turbidostat is an appropriate tool. It enables continuous growth of micro-organisms under constant and optimal culture conditions, and allows sampling without adversely interfering with growth. 


\section{Methods}

Organism and growth conditions. Axenic cultures of Synechocystis sp. strain PCC 6803 (a gift of the Department of Genetics, Moscow University) were grown in a modified $\left(\mathrm{CaCl}_{2} .2 \mathrm{H}_{2} \mathrm{O}, 110 \mathrm{mg} \mathrm{l}^{-1}\right.$; $\mathrm{NaCl}, 117 \mathrm{mg} \mathrm{l}^{-1}$; Tris, $485 \mathrm{mg} \mathrm{l}^{-1}$ ) medium of Allen \& Arnon (1955) in a turbidostat fitted with an intermittent pigment- and adherenceindependent control (Erdmann \& Schiewer, 1978). Microcystis firma strain Gromow 398 (Leningrad State University), was used in one experiment. Cultures were maintained at $29^{\circ} \mathrm{C}$, under continuous light $\left(20 \mathrm{~W} \mathrm{~m}^{-2}\right)$ and aerated with $\mathrm{CO}_{2}$-enriched air $(5 \%, \mathrm{v} / \mathrm{v})$. After several days, a constant specific growth rate was reached (steady state). The culture was then subjected to a severe salt shock, as described in Results.

The specific growth rate $\mu$ was calculated according to the equation: $\mu=D t^{-1} V^{-1}[D=$ effluent $(\mathrm{ml})$ during time $t(\mathrm{~h}), V=$ suspension volume $(700 \mathrm{ml})]$.

The increase in $\mathrm{NaCl}$ concentration in the culture vessel during the shock experiment was calculated from the dilution rate, according to the equation: $S=S_{R}\left(1-e^{-F t}\right)+S_{\mathrm{O}}$. Symbols: $S$, actual salinity $\left(\mathrm{g}^{-1}\right)$; $S_{\mathrm{R}}$, salinity in the reservoir vessel; $S_{\mathrm{O}}$, initial salinity in the culture vessel; $F$, flow rate (ml per culture volume); $t$, time (h).

Glucosylglycerol and glycogen-like polysaccharide. The cyanobacterial suspension $(2 \mathrm{ml})$ was centrifuged at $2000 \mathrm{~g}$ for $5 \mathrm{~min}$. The resultant pellet was extracted three times with $5 \mathrm{ml}$ boiling $80 \%(\mathrm{v} / \mathrm{v})$ ethanol for $3 \mathrm{~min}$. Pooled ethanolic extracts (the residues were used for glycogen assay) were dried on a rotary evaporator $\left(40^{\circ} \mathrm{C}\right)$ and the residue redissolved in $2 \mathrm{ml}$ water. A $1 \mathrm{ml}$ aliquot was hydrolysed by adding $2 \mathrm{M}$ $\mathrm{HCl}(0.3 \mathrm{ml})$ and heating at $100^{\circ} \mathrm{C}$ for $2 \mathrm{~h}$. The clear solution was cooled, and neutralized with $4 \mathrm{M}-\mathrm{NaOH}$. A $1 \mathrm{ml}$ sample was taken for enzymic glucose estimation using a glucose oxidase kit (Fermognost, VEB Arzneimittelwerk, Dresden). Apart from glucosylglycerol, negligible amounts of glucose and glucose-containing soluble material would have been included in these measurements.

Glycogen-like polysaccharide was estimated using the method of Warr et al. (1985). The cyanobacterial pellet (after ethanolic extraction) was suspended in $5 \mathrm{ml} 30 \%(\mathrm{w} / \mathrm{v}) \mathrm{KOH}$ and heated at $100^{\circ} \mathrm{C}$ for $1 \mathrm{~h}$. After centrifugation at $2000 \mathrm{~g}$ for $5 \mathrm{~min}, 1 \mathrm{ml}$ supernatant was mixed with $1.3 \mathrm{ml} 96 \%(\mathrm{v} / \mathrm{v})$ ethanol, boiled for $2 \mathrm{~min}$ and placed in a refrigerator overnight. The sample was centrifuged at $2000 \mathrm{~g}$ for $10 \mathrm{~min}$, and the pellet dissolved by heating at $100^{\circ} \mathrm{C}$ in $2 \mathrm{ml}$ water. After cooling and centrifugation, $1 \mathrm{ml}$ supernatant was mixed with $2 \mathrm{ml}$ anthrone reagent $\left(100 \mathrm{mg}\right.$ anthrone in $\left.50 \mathrm{ml} \mathrm{H}_{2} \mathrm{SO}_{4}\right)$, heated to $100^{\circ} \mathrm{C}$ for $15 \mathrm{~min}$ and then cooled. Absorbance was measured at $625 \mathrm{~nm}$ using a spectrophotometer (Zeiss).

Glucose-6-phosphate dehydrogenase (G6PDH, EC 1.1.1.49). Cyanobacterial suspension $(15 \mathrm{ml})$ was centrifuged at $2000 \mathrm{~g}$ for $5 \mathrm{~min}$, and the pellet washed with $50 \mathrm{mM}$-Tris/maleate, $\mathrm{pH} 7 \cdot 2$, containing $2 \mathrm{mM}$ $\mathrm{Na}_{2}$ EDTA and $3 \mathrm{~mm}-2$-mercaptoethanol. The pellet was homogenized for $2 \times 1 \mathrm{~min}$ using an ice-cooled cell mill (Bühler, Tübingen) after adding $1 \mathrm{ml}$ of glass beads (diam. $0 \cdot 1-0 \cdot 2 \mathrm{~mm}$ ). After centrifugation at $22000 \mathrm{~g}$ for $15 \mathrm{~min}$, the supernatant was used for measurements of enzyme activity.

The enzyme assay mixture contained $0 \cdot 1 \mathrm{ml}$ of crude protein extract, $0.5 \mathrm{ml}$ buffer (50 mM-Tris/maleate, $\mathrm{pH} 6.8,2 \mathrm{mM}-\mathrm{Na}_{2}$ EDTA), $0.1 \mathrm{ml}$ $\mathrm{NADP}^{+}$solution $\left(11 \mathrm{mg} \mathrm{ml}^{-1}\right)$. The reaction was initiated by adding $0.05 \mathrm{ml}$ of glucose 6-phosphate solution $\left(11 \mathrm{mg} \mathrm{m}^{-1}\right)$. The change in $A_{340}$ was continuously recorded at $30^{\circ} \mathrm{C}$ for $5 \mathrm{~min}$ (SP 800, Pye Unicam). Protein was determined by the Lowry method.

Photosynthesis and dark respiration. Photosynthetic and respiratory rates were measured using a Clark-type oxygen electrode (MV $85 \mathrm{~F}$, Metra Radebeul). The measurement was made with undiluted suspensions $(5 \mathrm{ml})$ under conditions similar to those of the turbidostat $\left(29^{\circ} \mathrm{C}, 20 \mathrm{~W} \mathrm{~m}^{-2}\right)$.

Cell number and mean diameter. Single and double cells, as well as larger cell aggregates, were counted on photographs taken using light microscopy. Biomass, cell number and mean diameter were determined with a particle size analyser using the Coulter principle (Laborscale, Medicor Budapest, Hungary). Cyanobacterial suspensions were diluted 500 -fold with filtered $\mathrm{NaCl}$ solution $(0.8 \%$, w/v) and analysed at the following settings: aperture, $75 \mu \mathrm{m}$; current, 100 $400 \mu \mathrm{A}$; lower discriminator, $50 \mathrm{mV}$; amplification, $\times 10^{5}$. The calculation of the mean diameter using the size distribution histogram (64 channels) was made as described (Heidenreich \& Sackrow, 1978).

Chlorophyll $a$. The suspension $(5 \mathrm{ml})$ was filtered through glass-fibre filters (SM 13400, Sartorius). The filters were dipped into $10 \mathrm{ml}$ methanol for $1 \mathrm{~h}$. Samples were centrifuged at $2000 \mathrm{~g}$ for $5 \mathrm{~min}$. The absorbance of the supernatant was measured at $665 \mathrm{~nm}$ and $\mathrm{Chl} a$ concentration was calculated using a specific absorption coefficient of $79 \cdot 241 \mathrm{~g}^{-1} \mathrm{~cm}^{-1}$ (Lichtenthaler, 1987).

All turbidostat experiments were repeated at least twice using independent cultures. One representative experiment was used for the figures. All assays were done in duplicate and averaged.

\section{Results}

In the first series of experiments, two independent turbidostat cultures of Synechocystis PCC 6803 were set to equal conditions such that the major growth parameters of both cultures were synchronous (Table 1, Fig. 1, day -1 to 0 ). The first culture was upshocked by the addition of crystalline $\mathrm{NaCl}$ to the culture vessel (sudden shock), whereas the second one was fed with $\mathrm{NaCl}$-containing medium from the reservoir vessel according to the growth rate (gradual shock). Fig. 1 (a) shows the resulting courses of $\mathrm{NaCl}$ enrichment in each of the cultures.

The progress of salt acclimation was different during the first two days (Fig. 1). In the suddenly, but not in the gradually shocked culture, growth and photosynthesis declined during the first hours (Fig. $1 b$ and $1 c$, respectively), with the greatest depression after about $10 \mathrm{~h}$. Partial restoration of growth and photosynthesis coincided with the accumulation of glucosylglycerol, which started immediately after the shock and was quite similar in both cultures (Fig. $1 d$ ). After 1.5 to $2 \mathrm{~d}$, growth and photosynthesis reached their maximal recovery. Although high levels of glucosylglycerol were accumulated and photosynthesis was almost fully active at this stage, the growth rate declined again and reached a minimum between the 6th and 8th day in both cultures. Thereafter a gradual recovery of growth led to saltacclimated cells after more than two weeks.

To verify this uncommon acclimation course, the sudden shock was investigated with another glucosylglycerol-accumulating freshwater cyanobacterium ( $\mathrm{Mi}$ crocystis firma) and in more detail in a second turbidostat series (Fig. 2). An immediate depression again occurred in growth and photosynthesis, and was also observed for 


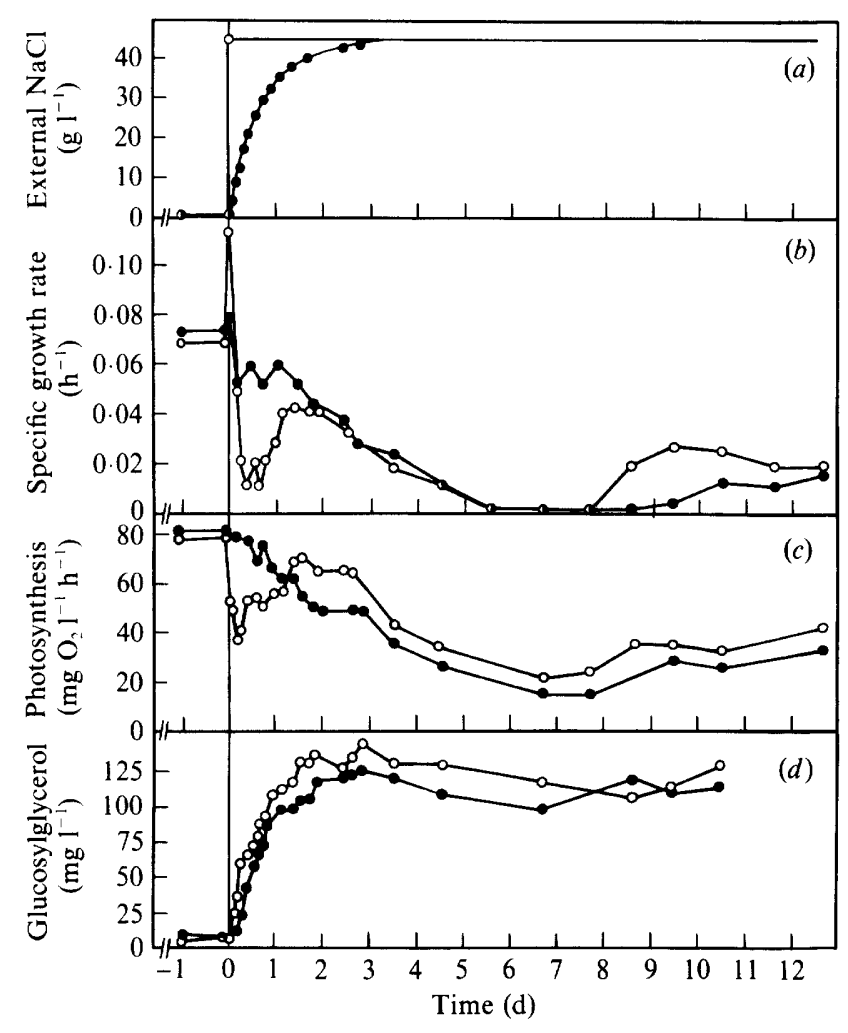

Fig. 1. Time courses of stress-relevant parameters after different hypertonic shocks $(770 \mathrm{~mm}-\mathrm{NaCl})$ on a freshwater-based culture of Synechocystis PCC 6803. Two independent turbidostat cultures were set to equal conditions (main growth parameters are given in Table 1). After reaching a steady state of growth (days -1 to 0 ), the cultures were shocked either suddenly (O) or gradually $(\bullet)$ at day 0 (vertical line). (a) Course of $\mathrm{NaCl}$ enrichment in the medium; (b) course of growth as determined from the dilution rate of the turbidostat; $(c)$ photosynthetic $\mathrm{O}_{2}$ evolution per litre of suspension; (d) glucosylglycerol accumulation in the cells per litre of suspension.

respiration, $\mathrm{Chl} a$ content and the G6PDH activity. Glucosylglycerol synthesis started without a lag phase after the shock and without a proportional decrease in glycogen content. Glycogen is often considered a possible precursor of glucosylglycerol and sucrose (Warr et al., 1985; Mackay \& Norton, 1987; Reed \& Stewart, 1988; Erdmann et al., 1989; Kerby et al., 1990) and interconversion of glycogen and glucosylglycerol has been shown to occur in the early period after illuminated salt shock in the marine cyanobacterium Agmenellum quadruplicatum (Tel-Or et al., 1986).

In our illuminated cultures, glucosylglycerol was assumed to be synthesized via photosynthetic $\mathrm{CO}_{2}$ assimilation (Fig. 2d). Although photosynthesis decreased to $20 \%$ of the non-shocked value in some experiments, the remaining $C$ fixation rate was 10 times more than that needed for glucosylglycerol synthesis [assuming the $C$ fixation rate at minimum was $12.59 \mathrm{mg}$ $1^{-1} \mathrm{~h}^{-1}$ and $\mathrm{C}$ demand for glucosylglycerol synthesis was

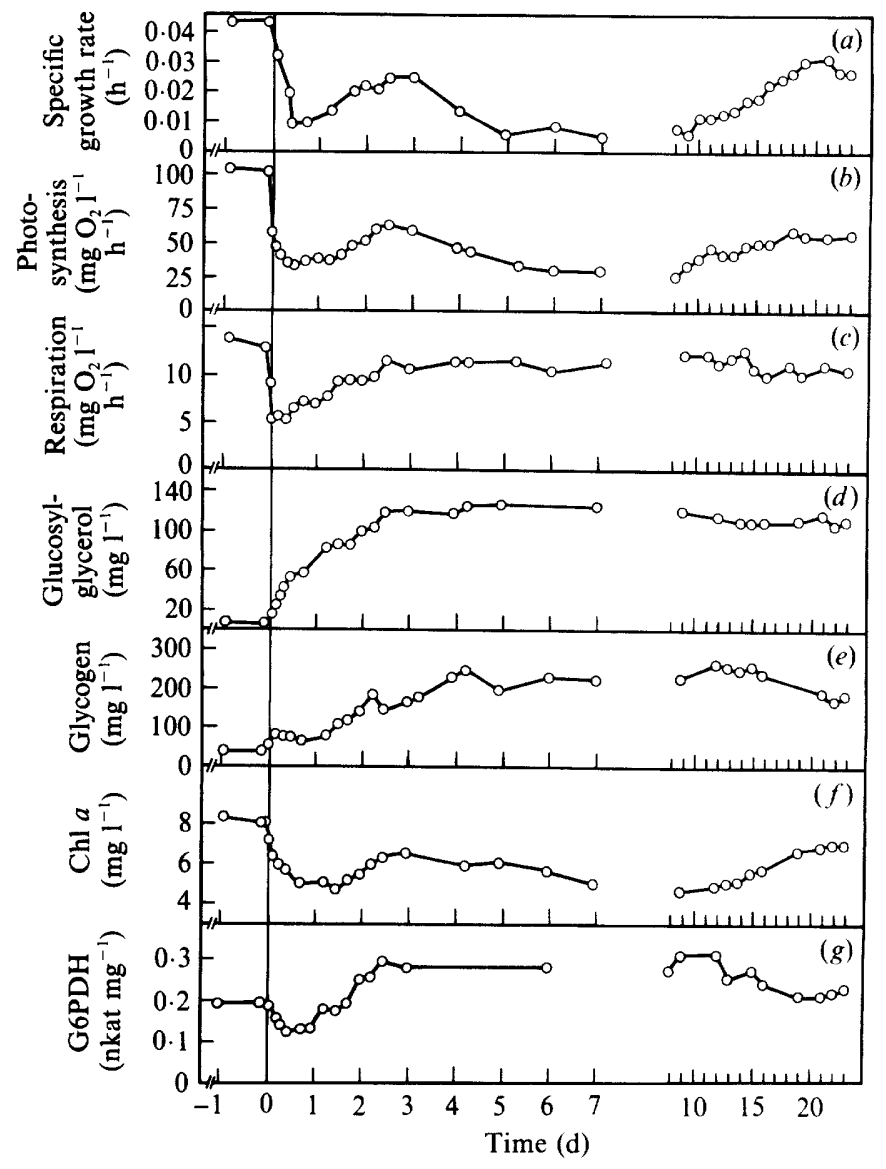

Fig. 2. Time course of salt acclimation after a sudden shock on a freshwater-based culture of $\boldsymbol{M}$. firma. Cells were grown in a turbidostat until a steady state of growth was reached (see Table 1). Day -1 to 0 , steady state; day 0 , sudden $\mathrm{NaCl}$ addition to $770 \mathrm{~mm}$; day 0 to 7 , acclimation course; days 8 to 23 , final recovery (compressed time scale). (a) Growth as determined from dilution rate; $(b, c)$ lightdependent $\mathrm{O}_{2}$ evolution and dark $\mathrm{O}_{2}$ consumption, respectively, per litre of suspension; $(d, e, f)$ contents of glucosylglycerol, glycogen and $\mathrm{Chl} a$, respectively, per litre of suspension after separation and extraction of the cells; $(g)$ specific G6PDH activity.

$1.30 \mathrm{mg} \mathrm{l}^{-1} \mathrm{~h}^{-1}$, when the accumulation rate of the first $10 \mathrm{~h}$ was averaged $\left.\left(4.59 \mathrm{mg}^{-1} \mathrm{~h}^{-1}\right)\right]$. Later, when the rate of glucosylglycerol synthesis diminished and growth became depressed (late depression), the excess of fixed carbon might be channelled into the glycogen-synthesizing pathway (Fig. 2e). This would explain the massive increase of glycogen and is consistent with the substantial increase in the number of glycogen granules reported previously (Schiewer \& Jonas, 1977; Potts et al., 1983; Lefort-Tran et al., 1988). Glycogen accumulation seems to be a general feature for bacteria exposed to stress (Potts et al., 1983; Shively et al., 1988).

Photosynthesis, respiration, G6PDH activity, Chl $a$ and growth increased in the same manner as glucosylglycerol content. When the maximum level of glucosyl- 
Table 1. Comparison of major steady state growth parameters of the different turbidostat series

\begin{tabular}{|c|c|c|c|c|c|c|}
\hline $\begin{array}{l}\text { Turbidostat } \\
\text { series }\end{array}$ & & $\begin{array}{c}10^{-6} \times \text { Cell } \\
\text { number } \\
\mathrm{ml}^{-1}\end{array}$ & $\begin{array}{c}\text { Doubling } \\
\text { time } \\
\left(\mathrm{h}^{-1}\right)\end{array}$ & $\begin{array}{c}\text { Chl } a \\
\text { content } \\
\left(\mathrm{mg} \mathrm{l}^{-1}\right)\end{array}$ & $\begin{array}{c}\text { Photosynthetic } \\
\text { rate } \\
{\left[\mu \mathrm{mol} \mathrm{O} \mathrm{O}_{2}\right.} \\
\left.(\mathrm{mg} \mathrm{Chl} a)^{-1} \mathrm{~h}^{-1}\right]\end{array}$ & Species \\
\hline (Fig. 1) & $\begin{array}{l}\mathbf{s} \\
\mathrm{g}\end{array}$ & $\begin{array}{l}74 \cdot 2 \\
69 \cdot 7\end{array}$ & $\begin{array}{r}10 \cdot 0 \\
9 \cdot 1\end{array}$ & $\begin{array}{l}\text { ND } \\
\text { ND }\end{array}$ & $\begin{array}{l}\text { ND } \\
\text { ND }\end{array}$ & $\begin{array}{l}\text { Synechocystis } \\
\text { PCC } 6803\end{array}$ \\
\hline 2 (Figs 2 and 3 ) & $\mathbf{s}$ & $81 \cdot 1$ & $15 \cdot 9$ & 8.04 & $396 \cdot 3$ & Microcystis firma \\
\hline (Fig. 4) & $\begin{array}{l}\text { s } \\
\text { g }\end{array}$ & $\begin{array}{l}112 \cdot 6 \\
121 \cdot 6\end{array}$ & $\begin{array}{l}15 \cdot 3 \\
17 \cdot 3\end{array}$ & $\begin{array}{l}7 \cdot 17 \\
7 \cdot 20\end{array}$ & $\begin{array}{l}426 \cdot 5 \\
414.8\end{array}$ & $\begin{array}{l}\text { Synechocystis } \\
\text { PCC } 6803\end{array}$ \\
\hline
\end{tabular}

ND, Not determined.

glycerol was reached, all parameters reached levels similar to those of salt-acclimated cells (Fig. 2).

The recovery processes coincided closely with an increase in cell size and in the ratio of double to single cells. This transition was monitored microscopically as well as electronically, using a particle size analyser. Microscopic cell analysis revealed both cell enlargement and cell aggregation. Cell counts showed a decline in the number of single cells from about $50 \%$ (non-shocked culture) to $5 \%$ with a parallel rise of double cells from 50 to $75 \%$ (Fig. $3 a$ ). In the size histogram drawn by the particle analyser, these changes resulted in the splitting of the single peak, typical for cells grown in standard medium, into two. In Fig. $3(b)$, this splitting is represented by the branching of the diameter curve. At the zenith of the depression, single cells were nearly absent and almost all cells were present as unseparated cell aggregates. Cell division was apparently disturbed at this stage. A similar situation can arise from the effect of dark on cyanobacterial cell cycle events. Limitation of light stopped or slowed the cell cycle and arrested a certain fraction of the population in the doublet stage (Marino \& Asato, 1986; Waterbury et al., 1986; Armbrust et al., 1989).

The late depression of growth could only partly be associated with an inhibition of cell metabolism (Fig. 2): respiration, glycogen synthesis and G6PDH remained active. G6PDH showed enhanced activity during the acclimation course and might cooperate with respiration, which is known to be integrated with the active exclusion of $\mathrm{Na}^{+}$ions (Molitor et al., 1990).

Eighteen days after the sudden shock, the growth rate reached a value typical for salt-acclimated cells (about $0.03 \mathrm{~h}^{-1}$ in this experiment). Assuming this value was the growth rate of at least a few cells during the whole acclimation course, they would have undergone about 18 cell doublings.

In a third series of turbidostat experiments (Fig. 4) a

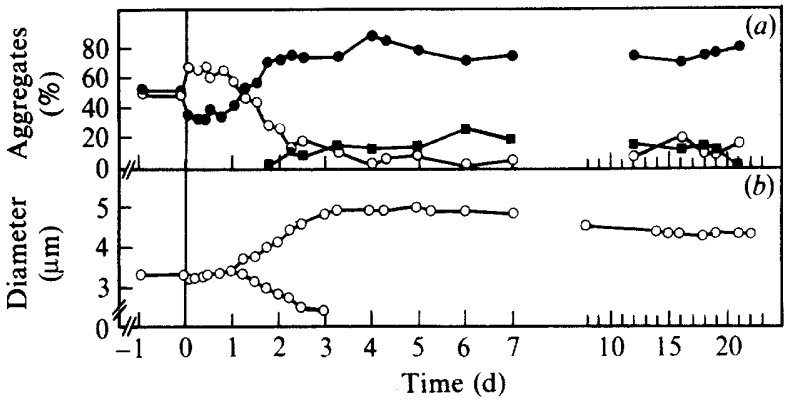

Fig. 3. Size and aggregation state of $M$. firma cells during the salt acclimation process shown in Fig. 2. (a) Composition of the population, as determined by microscopic cell counting $(O$, single cells;, , double cells; $\square$, higher aggregates); (b) mean diameter of the cells estimated by particle size analyser; branching represents the transformation of single (lower curve) into aggregated (upper curve) cells.

culture of Synechocystis PCC 6803 was used which had been previously upshocked (to $600 \mathrm{~mm}$ ) and then readjusted to freshwater conditions (each for 3 weeks, pretreated population). In contrast to the other two turbidostat experiments, a salt shock of $770 \mathrm{~mm}-\mathrm{NaCl}$ had no dramatic consequences (Fig. 4). The acclimation period was only $3 \mathrm{~d}$ (4 doublings) for both suddenly and gradually shocked cultures, and productivity in the new steady state was only slightly reduced (growth rate by less than $10 \%$, photosynthesis by about $20 \%$ ). Only the suddenly shocked cells showed an immediate depression: growth and photosynthesis reached a minimum after $14 \mathrm{~h}$ and recovered within $3 \mathrm{~d}$; the late depression was completely absent.

The more rapid acclimation of the pretreated population to $770 \mathrm{~mm}-\mathrm{NaCl}$ was not the result of a more efficient accumulation of glucosylglycerol (Fig. 4d). Its accumulation started from nearly zero with the usual kinetics and to the usual internal concentration that counterbalanced approximately $25 \%$ of the external osmolality (medium of $1.4 \mathrm{osmol} \mathrm{kg}^{-1}$; pretreated cells of $312 \pm 48 \mathrm{mM}$; non-pretreated cells of $357 \pm 137 \mathrm{mM}$; 


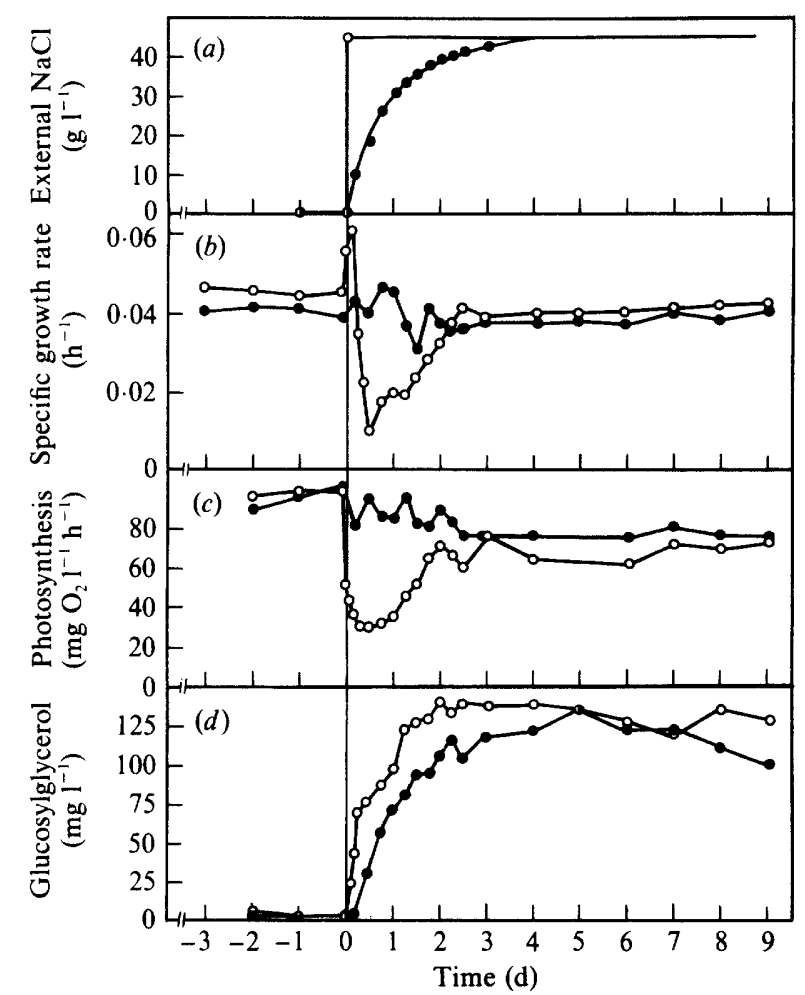

Fig. 4. Time courses of stress-relevant parameters after different hypertonic shocks on a pre-treated culture (preceding $\mathrm{NaCl}$ acclimation and re-acclimation to standard medium) of Synechocystis PCC 6803 (for further details see Table 1 and Figs 1 and 2).

values are means of one and four experiments, respectively, with confidence intervals for $95 \%$ probability; calculation based on whole cell volume). The value of $25 \%$ is similar to reported data ( $>20$ to $<40 \%$ ) of Reed \& Stewart (1988) and Reed et al. (1985).

Compared to the sudden shock, the accumulation of glucosylglycerol was slightly retarded in gradually shocked cells (Figs. 1 and 4). It is unclear whether this difference was the result of either lower synthesis rates (caused by small $\mathrm{NaCl}$ gradients) or faster biovolume increases (noninhibited growth).

\section{Discussion}

Synechocystis PCC 6803 was subjected to severe salt shocks $(770 \mathrm{mM})$ near the tolerance limit (about $1 \mathrm{M})$ to determine the importance of glucosylglycerol accumulation as a major subprocess of salt acclimation. Two different types of growth depression were observed. First, an immediate cessation which occurred in all sudden shocks and is well-known for both turbidostat and batch cultures (Blumwald \& Tel-Or, 1984; Vonshak et al., 1988; Sadka et al., 1989). The depression culminated at about $12 \mathrm{~h}$, impaired photosynthesis, respiration and G6PDH activities, and was overcome in parallel with the accumulation of glucosylglycerol. This supported the view that compatible solutes possess protective functions (Schobert, 1980). No immediate depression was observed in gradually shocked cultures.

Second, a late depression was observed in all previously non-shocked cultures, but was absent in all $\mathrm{NaCl}$ pretreated cultures. The growth depression culminated after about $7 \mathrm{~d}$, and was characterized by most of the cells arresting at a two-cell stage. This type of depression was restricted to high-strength shocks; a shock of minor strength (600 instead of $770 \mathrm{~mm}-\mathrm{NaCl})$ did not induce this depression (data not shown). To overcome this late depression (after the 8th day), there must have been either selection of a few cells capable of growth in $770 \mathrm{~mm}-\mathrm{NaCl}$, giving rise to a new population, or adaptation by the entire cell population. The latter requires differential gene expression, and is assumed to occur in Dunaliella cells (Ginzburg et al., 1990), and Sorghum seedlings (Amzallag et al., 1990), both of which showed a similar late growth depression when exposed to high salt concentrations. Here, however, selection of salttolerant cells seems more probable, because the pretreated cultures hold the re-acclimation ability for a long time [at least 3 weeks, in contrast to $2.5 \mathrm{~h}$ for Dunaliella cells (Ginzburg et al., 1990)].

The late depression appeared after glucosylglycerol had been accumulated in stress-relevant amounts. This led us to conclude firstly, that all cells must be able to synthesize glucosylglycerol when exposed to stress, and secondly, that glucosylglycerol is a necessary, but not totally sufficient, prerequisite of salt acclimation.

Part of the work was supported by a grant from the Fonds der Chemischen Industrie, FRG. The critical help of Dr D. N. Thomas and the technical assistance of Chem.-Ing. K. Sommerey and Mrs I. Dörr are gratefully acknowledged.

\section{References}

Allen, M. B. \& ARnon, D. I. (1955). Studies on nitrogen-fixing bluegreen algae. I. Growth and nitrogen fixation by Anabaena cylindrica Lemm. Plant Physiology 30, 366-372.

Amzallag, G. N., LeRner, H. R. \& Poljakoff-Mayber, A. (1990). Induction of increased salt tolerance in Sorghum bicolor by $\mathrm{NaCl}$ treatment. Journal of Experimental Botany 41, 29-34.

APTE, S. K. \& BHAGWAT, A. A. (1989). Salinity-stress-induced proteins in two nitrogen-fixing Anabaena strains differentially tolerant to salt. Journal of Bacteriology 171, 909-915.

APTE, S. K., ReDDY, B. R. \& Thomas, J. (1987). Relationship between sodium influx and salt tolerance of nitrogen fixing cyanobacteria. Applied and Environmental Microbiology 53, 1934-1939.

Armbrust, E. V., Bowen, J. D., Olson, R. J. \& Chisholm, S. W. (1989). Effect of light in the cell cycle of a marine Synechococcus strain. Applied and Environmental Microbiology 55, 425-432. 
Blumwald, E \& Tel-Or, E. (1984). Salt adaptation of the cyanobacterium Synechococcus 6311 growing in a continuous culture (turbidostat). Plant Physiology 74, 183-185.

Csonka, L. N. (1989). Physiological and genetic responses of bacteria to osmotic stress. Microbiological Reviews 53, 121-147.

ERdmanN, N. \& Schiewer, U. (1978). Turbidostat culture of bluegreen algae. II. Control system independent of pigmentation and organism adherence. Archiv für Hydrobiologie, Suppl. 51, Algological Studies 21, 456-467.

ErdmanN, N., Berg, C. \& Hagemann, M. (1989). Missing salt adaptation of Microcystis firma (cyanobacterium) in the dark. Archiv für Hydrobiologie 114, 521-530.

GIMMLER, H. \& HARTUNG, W. (1988). Low permeability of the plasma membrane of Dunaliella parva for solutes. Journal of Plant Physiology 133, 165-172.

GinzBurG, M., Weizinger, G., COHEN, M. \& GinzBurg, B. Z. (1990). The adaptation of Dunaliella to widely-differing salt concentrations. Journal of Experimental Botany 41, 685-692.

Hagemann, M., ErdmanN, N. \& Wittenburg, E. (1989). Studies concerning enzyme activities in salt-loaded cells of the cyanobacterium Microcystis firma. Biochemie und Physiologie der Pflanzen 184, $87-94$.

HaGemanN, M., Wölfel, L. \& KRÜGER, B. (1990). Alterations of protein synthesis in the cyanobacterium Synechocystis sp. PCC 6803 after a salt shock. Journal of General Microbiology 136, 1393-1399.

HeIDENREich, E. \& SACKROW, G. (1978). Zur granulometrischen Analyse grobdisperser Stoffe mit dem Teilchengrößenanalysator 'Laborscale'. Labortechnik 11, 16-20.

Jeanjean, R., Onana, B., Peschex, G. A. \& Joset, F. (1990). Mutants of the cyanobacterium Synechocystis PCC 6803 impaired in respiration and unable to tolerate high salt concentrations. FEMS Microbiology Letters 68, 125-130.

KeRBY, N. W., ReED, R. H. \& Rowell, P. (1990). Incorporation of ${ }^{14} \mathrm{C}$ in the cyanobacterium Synechococcus PCC 6301 following salt stress. Planta 181, 393-398.

KIRST, G. O. (1990). Salinity tolerance of eukaryotic marine algae. Annual Review of Plant Physiology and Plant Molecular Biology 41, 21-53.

Lefort-Tran, M., Pouphile, M. \& Spath, S. (1988). Cytoplasmic membrane changes during adaptation of the fresh water cyanobacterium Synechococcus 6311 to salinity. Plant Physiology 87, 767-775.

LiCHTENTHALER, H. K. (1987). Chlorophylls and carotenoids. Pigments of photosynthetic biomembranes. Methods in Enzymology 148, 350382.

MACKAY, M. A. \& NoRTON, R. S. (1987). ${ }^{13}$ C nuclear magnetic resonance study of biosynthesis of glucosylglycerol by a cyanobacterium under osmotic stress. Journal of General Microbiology 133, 15351542.

Marino, G. T. \& Asato, Y. (1986). Characterization of cell cycle events in the dark in Anacystis nidulans. Journal of General Microbiology 132, 2123-2127.

Molitor, V., Trnka, M., Erber, W., Steffan, I., Rivière, M.-E., ARRIO, B., SPRINGer-Lederer, H. \& PESCHEK, G. A. (1990). Impact of salt adaptation on esterified fatty acids and cytochrome oxidase in plasma and thylakoid membranes from the cyanobacterium Anacystis nidulans. Archives of Microbiology 154, 112-119.
Potts, M., Ocampo-Friedmann, R., Bowman, M. A. \& Tözun, B. (1983). Chroococcus S24 and Chroococcus N41 (cyanobacteria) morphological, biochemical and genetic characterization and effects of water stress on ultrastructure. Archives of Microbiology 135, 81-90.

ReEd, R. H. \& StewarT, W. D. P. (1988). The responses of cyanobacteria to salt stress. In Biochemistry of the Algae and Cyanobacteria, vol. 12, pp. 217-231. Edited by L. J. Rogers \& J. R. Gallon. Oxford: Clarendon Press.

Reed, R. H., WarR, S. R. C., Richardson, D. L., MOORE, D. J. \& STEWART, W. D. P. (1985). Multiphasic osmotic adjustment in a euryhaline cyanobacterium. FEMS Microbiology Letters 28, 225229.

Rivière, M.-E., ARrio, B., StefFan, I., Molitor, V., KuntNer, O. \& PESCHEK, G. A. (1990). Changes of some physical properties of isolated and purified plasma and thylakoid membrane vesicles from the freshwater cyanobacterium Synechococcus 6301 (Anacystis nidulans) during adaptation to salinity. Archives of Biochemistry and Biophysics 280, 159-166.

Russell, N. J. (1989). Adaptive modifications in membranes of halotolerant and halophilic microorganisms. Journal of Bioenergetics and Biomembranes 21, 93-113.

SadKa, A., Lers, A., Zamir, A. \& Avron, M. (1989). A critical examination of the role of de novo protein synthesis in the osmotic adaptation of the halotolerant alga Dunaliella. FEBS Letters 244, 93 98.

SCHIEWER, U. \& JoNAS, L. (1977). Influence of different $\mathrm{NaCl}$ concentrations on the ultrastructure of blue-green algae. I. Microcystis firma. Archiv für Protistenkunde 119, 127-145.

Shively, J. M., Bryant, D. A., Fuller, R. C., Konopka, A. E., STEVENS, S. E., JR \& STROHL, W. R. (1988). Functional inclusions in prokaryotic cells. International Review of Cytology 113, 35-100.

SCHOBERT, B. (1980). The importance of water activity and water structure during hyperosmotic stress in algae and higher plants. Biochemie und Physiologie der Pflanzen 175, 91-103.

Tel-OR, E., SPAth, S., PACKer, L. \& Mehlhorn, R. J. (1986). Carbon13 NMR studies of salt-induced carbohydrate turnover in the marine cyanobacterium Agmenellum quadruplicatum. Plant Physiology 82, 646-652.

TrẗPER, H. G. \& Galinski, E. A. (1989). Compatible solutes in halophilic phototrophic prokaryotes. In Microbial Mats, Physiological Ecology of Benthic Microbial Communities, pp. 342-348. Edited by Y. Cohan \& E. Rosenberg. Washington DC: American Society for Microbiology.

Vonshak, A., GUY, R. \& GUY, M. (1988). The response of the filamentous cyanobacterium Spirulina platensis to salt stress. Archizes of Microbiology 150, 417-420.

Wark, S. R. C., Reed, R. H., Chudek, J. A., Foster, R. \& Stewart, W. D. P. (1985). Osmotic adjustment in Spirulina platensis. Planta 163, 424-429.

Waterbury, J. B., Watson, S. W., Valois, F. W. \& Franks, D. G (1986). Biological and ecological characterization of the marine unicellular cyanobacteria Synechococcus. Canadian Bulletin of Fisheries and Aquatic Sciences 214, 71-120. 